\title{
Treadmill Training Effects on Neurological Outcome After Middle Cerebral Artery Occlusion in Rats
}

\author{
Yea-Ru Yang, Ray-Yau Wang, Paulus Shyi-Gang Wang, Shang-Ming Yu
}

\begin{abstract}
Background: Treadmill training is used for promoting rhythmical vigorous walking and for task-related training in patients with stroke. The neurological impact of treadmill training has not been established. The present investigation is aimed at (1) examining neurological changes over a fourweek period after middle cerebral artery occlusion (MCAO) in rats and (2) assessing the impact of oneweek, two-week and four-week treadmill training in MCAO rats. Methods: Male Sprague-Dawley rats were subjected to 60-minute right MCAO. All rats were randomly assigned to one of seven groups. Infarct volume and neurological score were measured. Results: Rats sacrificed 24 hours post MCAO had the largest infarct volumes $\left(171.4 \pm 14.4 \mathrm{~mm}^{3}\right)$ and the highest neurological score (median: 2, range: 1-3). We noted that without treadmill training, infarct sizes and neurological score diminished with time. Treadmill training for at least one week further reduced infarct volume and significantly improved neurologic function in MCAO rats. Conclusion: Treadmill training after focal cerebral ischemia significantly improves neurological outcome in MCAO rats. Treadmill training may be beneficial for ischemic brain recovery.
\end{abstract}

RÉSUMÉ: Effets de l'entraînement sur tapis roulant sur l'issue neurologique chez des rats ayant subi une occlusion de l'artère cérébrale moyenne. Introduction: L'entraînement sur tapis roulant est utilisé pour promouvoir la marche rythmique rapide et l'entraînement à la tâche chez les patients ayant subi un accident vasculaire cérébral. L'impact neurologique de l'entraînement sur tapis roulant n'a jamais été étudié. Cette étude vise à: 1) examiner les changements neurologiques qui surviennent dans les quatre premières semaines après l'occlusion de l'artère cérébrale moyenne (OACM) chez des rats et d'évaluer l'impact d'un entraînement sur tapis roulant de une, deux et quatre semaines chez des rats ayant subi une OACM. Méthodes: Des rats mâles Sprague-Dawley ont subi une OACM d'une durée de 60 minutes. Ils ont été divisés en sept groupes. Le volume de l'infarctus et le score neurologique ont été mesurés. Résultats: Les rats sacrifiés 24 heures après l'OACM avaient les plus gros infarctus (171,4 $\pm 14,4 \mathrm{~mm} 3)$ et le score neurologique le plus élevé (médiane: 2; écart: 1 à 3 ). Sans entraînement sur tapis roulant, la taille de l'infarctus et le score neurologique diminuaient avec le temps. L'entraînement sur tapis roulant pendant au moins une semaine diminuait davantage le volume de l'infarctus et améliorait significativement la fonction neurologique des rats ayant subi une OACM. Conclusions: L'entraînement sur tapis roulant après une ischémie cérébrale focale améliore significativement l'issue neurologique chez les rats ayant subi une OACM. L'entraînement sur tapis roulant peut avoir un effet bénéfique sur la récupération après une ischémie cérébrale.

Can. J. Neurol. Sci. 2003; 30: 252-258

Although some spontaneous recovery can occur following focal cerebral ischemia, rehabilitation may hasten or improve the outcome. It is a common practice in stroke centers to start training programs for patients at an early stage after cerebral infarction. Evaluations have confirmed that early mobilization reduces secondary complications and mortality and promotes long-term functional benefits. ${ }^{1}$ Stroke patients who receive organized inpatient care in a stroke unit are more likely to survive and to achieve functional independence. ${ }^{2}$ This organized care is characterized by early mobilization and multidisciplinary rehabilitation coordinated by regular team meetings. The optimum program of rehabilitation after a stroke, however, is not identified. ${ }^{3,4}$ Also, it is not known if, or how, rehabilitation influences the recovery process after cerebral infarction.

Ambulation is a primary functional goal for many stroke

From the Faculty and Institute of Physical Therapy (Y-RY, R-YW); Department and Institute of Physiology (PS-GW); Institute of Anatomy and Cell Biology (S-MY), National Yang-Ming University, Shih-Pai, Taipei, Taiwan.

Received June 24, 2002. ACCEPTED In Final Form February 24, 2003. Reprint requests to: Ray-Yau Wang, Faculty and Institute of Physical Therapy, National Yang-Ming University, 155, Sec 2, Li-Nong St., Shih-Pai, Taipei, Taiwan. 
patients. Intervention for stroke patients typically includes a program of gait training. The treadmill apparatus was developed to provide a useful tool in both gait research and gait rehabilitation. Since 1982, it has been suggested that treadmill walking provides walking training, ${ }^{5}$ following the findings from investigations of the spinalization in the cat. ${ }^{6}$ Forced use engendering a repetitive motor task may best promote central neural plasticity. ${ }^{7}$ Finch et $\mathrm{al}^{8}$ also supported this dynamic approach to gait training in humans. Human studies have shown that treadmill training improved gross motor efficiency and physiologic reserve in stroke patients. ${ }^{9-11}$ Recently, treadmill walking has been shown to be effective in promoting rhythmical walking and is a useful method for training after a stroke. ${ }^{12,13}$ The neurological effects of treadmill training in stroke patients have not been established and its potential mechanism is uncertain.

Middle cerebral artery occlusion (MCAO) resulting in ischemic brain damage in rats has been used since $1975 . .^{14,15}$ This techniques is considered to be a reliable and reproducible model of cerebral ischemia. ${ }^{16,17}$ Damage following MCAO in rats develops in the striatum and overlying cortex, similar to that observed in human thrombotic/embolic occlusion of the middle cerebral artery (MCA). ${ }^{18,19}$ Also, MCAO in rats causes neurologic deficits that can readily be assessed. ${ }^{20,} 21$ The purposes of the present study were to examine the character of neurological changes from 24 hours to four weeks after MCAO and to assess the effects of treadmill training in MCAO rats.

\section{METHODS}

\section{Animals}

Adult male Sprague-Dawley rats, between two and three months of age, were used in this study. All rats were housed in groups of two and maintained under a 12 hour light/dark cycle with food and water available ad libitum. The MCAO procedure and treadmill training were performed during the light phase. All rats were randomly assigned to one of the seven groups. The experimental design for each group is outlined in Table 1. The study protocol was reviewed and approved by the institutional animal care committee.

\section{MCAO procedures}

Middle cerebral artery occlusion procedure leading to focal ischemia was conducted under chloral hydrate anesthesia (a single $0.5 \mathrm{~g} / \mathrm{kg}$ i.p. bolus in $1 \mathrm{ml}$ of saline provided anesthesia lasting at least two hours). Rectal temperature was monitored throughout the surgical procedures and maintained at $37.0 \pm$ $0.5^{\circ} \mathrm{C}$ by a heating lamp and a heating blanket controlled by an electronic temperature controller (HB 101/2, Debiomed).

The right middle cerebral artery was exposed using microsurgical techniques. ${ }^{16,17}$ Briefly, a 2-mm burr hole was drilled at the junction of the zygomatic arch and the squamous bone, following a $2-\mathrm{cm}$ vertical skin incision midway between the right eye and ear and splitting of the temporalis muscle. The right middle cerebral artery trunk was ligated immediately above the rhinal fissure with 10-0 suture. Complete interruption of blood flow was confirmed using an operating microscope. Both common carotid arteries were then occluded using nontraumatic aneurysm clips. After the predetermined duration of ischemia (60 minutes), the aneurysm clips and ligation were removed from both common carotid arteries and middle cerebral artery. Restoration of blood flow in all three arteries was observed directly under the microscope. After recovery from anesthesia, all rats were kept in individual cages for the first 24 postoperative hours. Rats were then returned to their cages with free access to food and water for the remainder of the one-week, two-week or four-week period.

\section{Treadmill training protocol}

A motor driven treadmill (Treadmill Simplex II, Columbus Instruments, U.S.A.) was used for training. Before MCAO procedures, all rats were placed on the already moving belt facing away from the electrified grid and ran in the direction opposite of the movement of the belt over a three-day accommodation period. This was to let rats move forward in order to avoid foot shocks (with intensity in $1.0 \mathrm{~mA}$, Stimulus Controller Model D48E, DRI Co., Taiwan). Only the rats that had learned to run were included in the present study. At the end of the adaptation period, the included rats were randomly assigned to one of the seven groups. Four of the seven groups were no-training groups (Table 1). Rats in these four groups remained sedentary in their cages for a 24-hour, one-week, twoweek or four-week period after MCAO. The other three groups were treadmill-training groups (Table 1). Three different treadmill-training conditions were set; training commenced 24 hours after MCAO for a period of one-week, two-weeks or fourweeks respectively. Rats were trained for 30 minutes per day,

Table 1: Experimental design

\begin{tabular}{lllll}
\hline Group & Number & $\begin{array}{l}\text { Timing for } \\
\text { Treadmill Training }\end{array}$ & $\begin{array}{l}\text { Duration of } \\
\text { Treadmill Training }\end{array}$ & $\begin{array}{l}\text { Timing for Sacrifice } \\
\text { post MCAO* } \\
\text { MCA }\end{array}$ \\
1 & 11 & - & - & one week \\
2 & 10 & - & - & two weeks \\
3 & 11 & - & - & four weeks \\
4 & 10 & - & - & one week \\
5 & 10 & 24 hours post MCAO & one week & two weeks \\
6 & 10 & 24 hours post MCAO & two weeks & four weeks \\
7 & 11 & 24 hours post MCAO & four weeks & \\
\hline
\end{tabular}

*MCAO: middle cerebral artery occlusion 


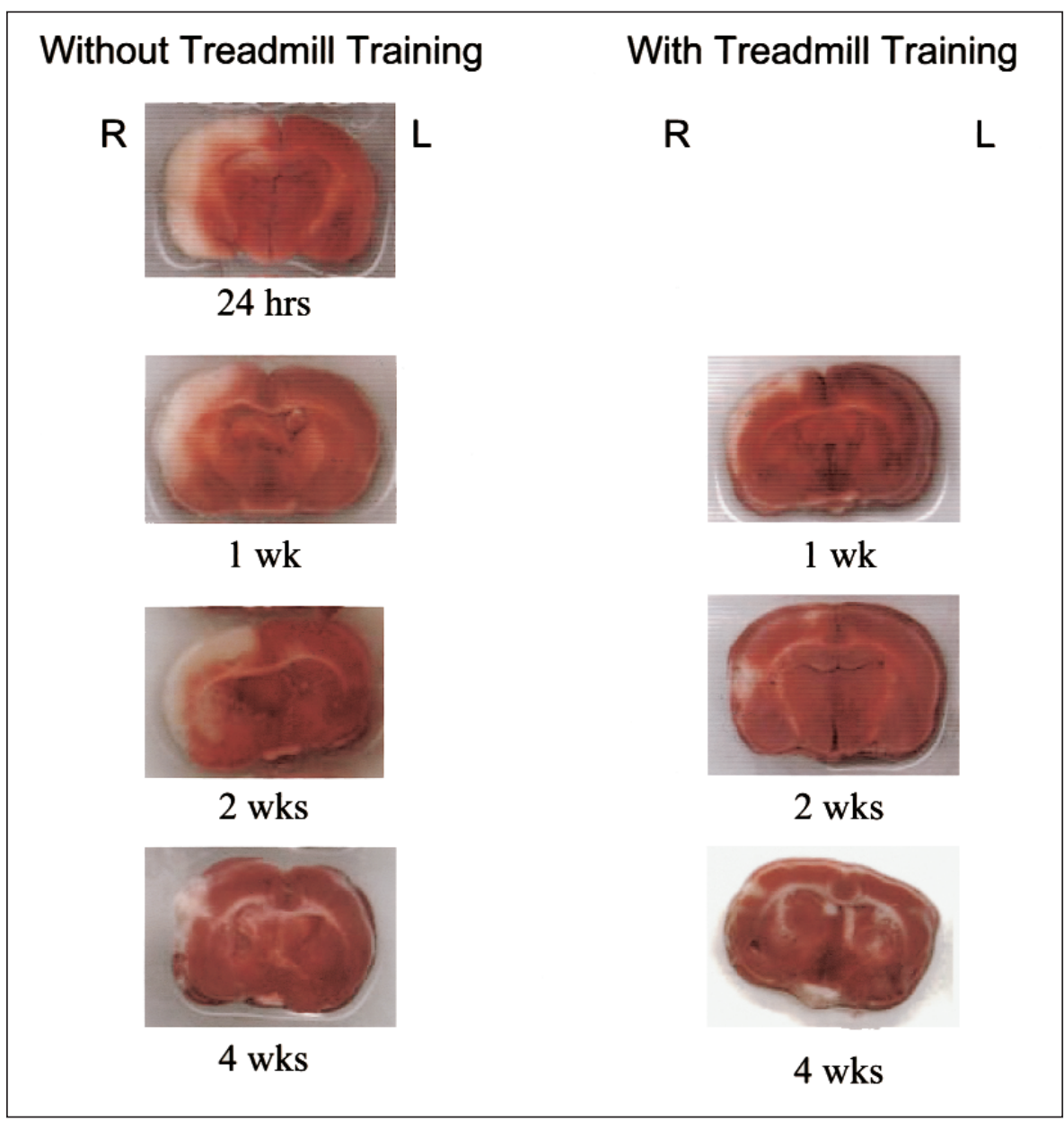

Figure 1: Delineation of infarct volume with TTC from each condition after middle cerebral artery occlusion in rats.

five days per week to run on the treadmill at a speed of 20 meters/min with a slope of $0^{\circ}$.

\section{Neurological examination}

The investigator who performed the neurological examination was blinded to the type of experimental procedure performed. A neurologic grading system with a five-point scale $(0-4)$ described by Menzies et $\mathrm{al}^{22}$ was used to assess the motor

Table 2: Evaluation criteria for neurological examination of rats after middle cerebral artery occlusion ${ }^{22}$

\begin{tabular}{ll}
\hline Score & Evaluation \\
0 & No apparent deficits \\
1 & Left forelimb flexion \\
2 & Decreased grip of the left forelimb while tail pulled \\
3 & Spontaneous movement in all directions; left circling only \\
& if pulled by tail \\
4 & Spontaneous left circling
\end{tabular}

and behavioral changes after the MCAO (Table 2). The tests described below were conducted sequentially. If a rat exhibited the appropriate behavior at one step but not at the subsequent step, it was graded as the former. Rats were held gently by the tail, suspended at $30 \mathrm{~cm}$ above the floor, and their forelimb posture was noted. Normal rats that extended both forelimbs toward the floor and that had no other neurological deficit were assigned a score of 0 . Rats that flexed the forelimb contralateral to the hemisphere of the MCAO during the suspension and had no other abnormality were assigned a score of 1 . Rats were placed on a large absorbent pad that could be gripped firmly by their claws. If rats showed an apparent decrease in grip in the contralateral forelimb when being pulled by the tails, they would be assigned a score of 2 . While still being held by the tails, rats were then allowed to move freely and were observed for their circling behavior. Rats that are still capable of moving in all directions but only circled toward the paretic side when given a slight jerk of the tails were assigned a score of 3. Rats that circled toward the paretic side consistently were assigned a score of 4 . Rats that were graded 0 indicate normal and rats that were graded 4 indicate severe neurological deficit. 


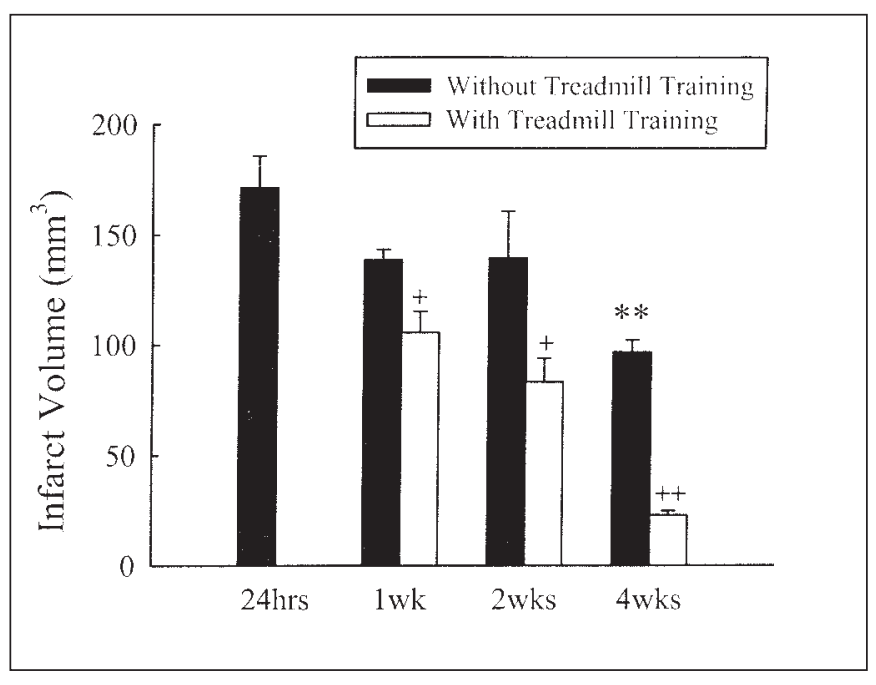

Figure 2: Infarct volume as mean \pm SEM at various time intervals with or without treadmill training after middle cerebral artery occlusion in rats. ** $p<0.01$ versus the 24 hours after middle cerebral artery occlusion. $+p<0.05,++p<0.01$ versus the same postocclusion period without treadmill training.

\section{Quantitative analysis of infarct volume}

After periods of 24-hours, one-week, two-weeks and fourweeks, rats were sacrificed under ketamine anesthesia by intracardiac perfusion with $200 \mathrm{ml}$ of $0.9 \% \mathrm{NaCl}$. The brain was removed and dissected into coronal $2-\mathrm{mm}$ sections using a brain slicer. The fresh brain slices were immersed in a $2 \%$ solution of 2,3,5-triphenyltetrazolium chloride (TTC) in normal saline at $37^{\circ} \mathrm{C}$ for 30 minutes, and then fixed in $10 \%$ phosphate-buffered formalin at $4^{\circ} \mathrm{C} .{ }^{16,17}$ Unstained areas on each brain slice, defined as infarction area (Figure 1), were then measured by an image analyzer (Image-Pro Plus). The damaged areas measured were cerebral cortex including the adjacent caudate nucleus, putamen, and hippocampus. Total measured infarct volume (MV) for each brain was calculated by summation of the infarcted area of all brain slices (area of infarct in square millimeters times thickness, $2 \mathrm{~mm}$ ) from the same hemisphere. Both right hemisphere volume (RV) and left hemisphere volume (LV) were measured and calculated. To compensate for the effect of brain edema on MV in the ischemic hemisphere at 24 hours post MCAO, corrected infarct volume was calculated by the following formula, as previously described: corrected infarct volume $=\mathrm{LV}-(\mathrm{RV}-$ MV). ${ }^{23,24}$ Resolution of the brain edema was observed at oneweek post MCAO. Therefore the infarct volume was computed as the MV at one week, two weeks, and four weeks post MCAO.

\section{Statistical analysis}

Infarct volumes were expressed as means \pm standard error of means. The time effect on infarct volume was tested for homogeneity using the one-way analysis of variance (ANOVA) with time as between-group variable, and the difference between specific means was tested for significance using Duncan's multiple-range test. To examine the treadmill training effect on infarct volume, the independent $t$ test was employed.

Neurological scores were expressed as median and range. The
Table 3: Neurological score post middle cerebral artery occlusion (MCAO) in Rats

\begin{tabular}{clll}
\hline & Group & Number & $\begin{array}{l}\text { Neurological } \\
\text { Score }\end{array}$ \\
$\begin{array}{c}\text { Without Treadmill Training } \\
\text { 24 hours post MCAO }\end{array}$ & 1 & 11 & $2(1-3)$ \\
one week post MCAO & 2 & 10 & $2(0-3)$ \\
two weeks post MCAO & 3 & 11 & $2(0-3)$ \\
four weeks post MCAO & 4 & 10 & $0(0-1) * *$ \\
& & & \\
With Treadmill Training & & 10 & $0(0-3) \dagger$ \\
one week post MCAO & 5 & 10 & $0(0-0) \dagger \dagger$ \\
two weeks post MCAO & 6 & 11 & $0(0-0)$ \\
four weeks post MCAO & 7 & & \\
& & &
\end{tabular}

Neurological scores were expressed as median (range).

** $\mathrm{p}<0.005$ versus 24 hours post MCAO

$\dagger \mathrm{p}<0.05, \dagger \dagger \mathrm{p}<0.005$ versus the same postocclusion period without treadmill training

time effect on neurological score was examined by KruskalWallis analysis and the difference between two groups was further analyzed with Mann-Whitney U test. Comparison of treadmill training effect on neurological score was also carried out by Mann-Whitney $U$ test. A probability value of less than 0.05 was considered to be significant.

\section{RESULTS}

The mean infarct volume changed significantly with time after MCAO without treadmill training $(\mathrm{F}(3,38)=4.4, \mathrm{p}<0.01)$. The mean infarct volume was $171.4 \pm 14.4 \mathrm{~mm}^{3}$ measured at 24 hours after MCAO (Group 1), $138.8 \pm 4.7 \mathrm{~mm}^{3}$ at one week after MCAO (Group 2), $139.6 \pm 21.1 \mathrm{~mm}^{3}$ at two weeks after MCAO (Group 3), and $96.8 \pm 5.5 \mathrm{~mm}^{3}$ at four weeks after MCAO (Group 4). As illustrated in Figure 2, post-hoc analysis revealed a significant difference $(\mathrm{p}=0.0005)$ in mean infarct volume between 24 hours and four weeks after MCAO. The neurological score also changed significantly with time after MCAO without treadmill training $(\mathrm{p}=0.001)$. Individual comparison indicated that there was significant difference $(\mathrm{p}<0.001)$ between 24 hours (median score: 2) and four weeks after MCAO (median score: 0 ), as shown in Table 3.

The effects of the treadmill training were examined by comparing the infarct volume in rats after MCAO with and without training for the same postocclusion period. These comparisons were also presented in Figure 2. The one-week treadmill training after MCAO (Group 5) resulted in a decrease in infarct volume compared with one-week spontaneous recovery (Group 2) $(\mathrm{p}=0.01)$. Similar training effects were obtained when comparing the mean infarct volume between twoweek treadmill training group (Group 6) and two-week spontaneous recovery group (Group 3$)$ ( $p<0.05$ ), and between four-week treadmill training group (Group 7) and four-week 
spontaneous recovery group (Group 4) ( $<$ < 0.0001) (Figure 2). With regard to the neurologic function, significant differences in neurological score were obtained between the one-week treadmill training group and the one-week spontaneous recovery group ( $\mathrm{p}<0.05)$, and also between the two-week treadmill training group and the two-week spontaneous recovery group $(\mathrm{p}$ $<0.005$ ) (Table 3). No significant difference was recognized between the four-week treadmill training group and the fourweek spontaneous recovery group.

\section{DiscuSSION}

The present investigation shows two important findings. First, both infarct volume and neurologic function are time related. Second, treadmill training after focal brain ischemia for at least one week can significantly reduce infarct volume and improve neurologic function.

The present study showed that considerable neurological recovery occurred in MCAO rats, without treadmill training. The infarct volume and neurological score diminished significantly with time and there were significant differences between 24 hours and four weeks after MCAO, as demonstrated in Figure 2 and Table 3. Consistent with the present findings, Persson et $\mathrm{al}^{25}$ have addressed the importance of time for interpreting ischemic changes, and they also found that MCAO rats can survive for several weeks, during which period many will improve neurologically. These findings suggested that such spontaneous recovery resembled that seen in ischemic infarcts in humans.

Infarct volume is an important index for estimating ischemic cerebral injury. TTC staining has been proposed as a rapid, convenient, and reliable method for quantitatively delineating the infarct volume in experimental cerebral ischemia. ${ }^{16,26,27}$ TTC is a water-soluble salt that reacts with oxidative enzyme systems, such as succinate dehydrogenase on mitochondria. Normally, TTC is oxidized to a lipid soluble, bright red formazan by mitochondrial enzyme systems; therefore, normal tissues stain a dark red color when immersed in TTC. This reaction is lost in damaged mitochondria or oxidative systems, and the lack of staining should demarcate ischemic from normal brain tissue (Figure 1). To the best of our knowledge, there is no direct evidence elucidated that TTC unstained areas cover the ischemic penumbra. However, the TTC unstained area can be viewed as an infarcted tissue in which mitochondrial enzymes are denatured and dysfunctional. A considerable decrease of intact mitochondria has been verified in the unstained area. ${ }^{28}$ Since penumbral tissue is also metabolically perturbed, it is reasonable for our purposes to define that the TTC unstained area encompasses the ischemic core and penumbra.

Some studies have demonstrated correlation between infarct volume and neurological score after focal cerebral ischemia in rats. $^{25,} 29$ Furthermore, Witte ${ }^{30}$ indicated that ischemic brain lesions are surrounded by a dysfunctional zone. He speculated that the perilesional dysfunctional brain area contributes to the ensuing neurological deficit, and that recovery occurs when this perilesional dysfunction resolves. ${ }^{30}$ The present investigation showed that reduction of infarct volume was accompanied by improvement of neurologic function. Our present results support the inference addressed by Witte. ${ }^{30}$ However, focal brain damage not only causes a loss of function in the lesioned area, but also disturbs a connected brain network. Recent investigations suggested that focal brain lesion caused a hyperexcitability of widespread brain areas ipsilateral and even contralateral to the lesion. $^{31,32}$ Several studies supported that the lesion-induced hyperexcitability can develop a propensity for long-term potentiation and then contribute to restorative processes. ${ }^{33,} 34$ Taken together, these observations indicate that functional restoration may be partially the result of alleviation of perilesional dysfunction and partially the result of lesion-induced network plasticity in remote brain areas.

It has been suggested that further functional recovery can be achieved in experimental animals and humans with training. ${ }^{35-39}$ Treadmill training represents a functional activity and is purposeful bilateral hemisphere activity. Recent clinical studies have shown that treadmill training is effective with regard to restoration of gait ability and improvement of gross motor efficiency. ${ }^{9}, 10$ However, the neurological changes following treadmill training are far less certain. Therefore, in the present study, the character of the brain changes in MCAO rats for one week, two weeks, and four weeks with treadmill training was investigated. The present results showed that treadmill training over a period after MCAO (from one week to four weeks) could significantly reduce the infarction volume and improve neurologic function when compared to the same duration after MCAO without training (Figure 2 and Table 3).

The underlying mechanisms for effects of treadmill training on MCAO rats remain poorly understood. However, raising blood pressure and increasing oxygen delivery to the brain might be the contributing factors to mitigate ischemic brain damage. If the exercise involves a large proportion of the body musculature, such as in running or swimming, increase in blood pressure was observed. Arterial pressure started to rise with the onset of exercise, and the increase in blood pressure roughly paralleled the severity of the exercise performed. ${ }^{40}$ A previous study has shown that induced hypertension was effective in reversing ischemic deficits. ${ }^{41}$ Auer ${ }^{42}$ has also suggested that blood pressure is a critical determinant of infarct size, and raising blood pressure improves collateral blood flow and reduces stroke size. Furthermore, increase in cerebral blood flow and enhancement of cerebral oxygenation during exercise was demonstrated. ${ }^{43}$ Other investigators have studied the effects of oxygen delivery on cerebral protection. These results suggested that increasing cerebral oxygen, presumably by providing more oxygen to the region of the ischemic penumbra, could reduce cerebral infarct. ${ }^{44,45}$ Thus, it is possible that treadmill training influenced infarct size through a mechanism of cerebral hyperoxia. These results seem to indicate that exercise-induced hypertension as well as cerebral hyperoxia may have contributed to the recovery of the penumbral areas. It should be noted that body temperature also increased during exercise. Hyperthermia has been shown to have detrimental effects on outcome after MCAO. ${ }^{46}$ However, treadmill training resulted in a beneficial effect on MCAO rats in the present study. Hence, exercise induced hyperthermia may play a minor role on the effects of treadmill training after MACO. According to the concept of perilesional dysfunction as mentioned above, treadmill training might cause reduction of infarct size and mitigation of perilesional dysfunction and then contribute to functional restoration. Moreover, some investigations also suggested that lesion-induced network 
plasticity can be enhanced by rehabilitative training, thus allowing a recovery of neurologic function..$^{35,47}$

After a focal brain infarct, an increased neuronal labeling of microtubule-associated protein 2 , growth-associated protein 43 , and cyclin D1 immunoreactivity from day 2 and up to 28 days has been found in the penumbral zone. ${ }^{48}$ The selective expression of these proteins observed in the penumbral area suggests an active ongoing process of neuronal repair. Recently, Wei et $\mathrm{al}^{49}$ also demonstrated the appearance of neurogenesis in the cerebral cortex of adult rats, with the highest density in the ischemic boundary zone at 30 and 60 days after transient focal cerebral ischemia. Parallel with neurogenesis, angiogenesis was also found in the ischemic border at 30 days after ministroke. ${ }^{50}$ Taken together, neuron proliferation and growth of new capillaries in the penumbral area thus resulted in decreased infarct size after focal cerebral ischemia. Additionally, there is some evidence that exercise may induce neurogenesis and angiogenesis. Voluntary exercise in a running wheel has been demonstrated sufficient to enhance neurogenesis in the adult mouse dentate gyrus ${ }^{51}$ and to induce angiogenesis within motor cortex in rats. ${ }^{52}$ The neurogenesis and angiogenesis may account for our remarkable exercise-induced decrease in infarct size.

In the present study, our data showed that the one-week and two-week treadmill training after MCAO resulted in a significant decrease in infarct volume in addition to significant improvement in neurologic function compared with one-week and two-week spontaneous recovery, respectively. However, the four-week treadmill training after MCAO resulted in a significant decrease in infarct volume compared with four-week spontaneous recovery, but no significant difference was recognized in improvement of neurologic function between fourweek treadmill training group and four-week spontaneous recovery group (Table 3). The reason for four-week treadmill training causing no further improvement in neurologic function compared with four-week spontaneous recovery may be due to the ceiling effect of neurological scoring system. According to this observation, it is noteworthy that the neurological scoring system is less sensitive to smaller ischemic lesions.

The influence of early training after human cerebral infarction remains contradictory. Some studies report that general activation starting 24 hours after an ischemic event promotes functional outcome without increasing tissue loss. ${ }^{53,54}$ However, other reports indicate that intense early training might be deleterious. Humm et $\mathrm{al}^{55}$ found that forced overuse of the impaired forelimb during the first seven days after focal lesions of the forelimb sensorimotor cortex in rats caused expansion of neural injury and interfered with restoration of function. Risedal et $\mathrm{al}^{56}$ indicated that the specific training (one hour a day, five days a week) initiated 24 hours after focal brain ischemia can increase cortical tissue loss. Among these studies as mentioned above, one important variable is the intensity of training. Bland et $\mathrm{al}^{57}$ indicated that intensity of training appears to be one of the important factors that contribute to early use-dependent exaggeration of injury. Lower intensity physical training after brain injury has not shown to be deleterious but appears to promote reorganization of relevant cortical representation areas with functional improvements. ${ }^{35}$ In the present study, the intensity of treadmill training for 30 minutes per day, five days per week seems to be a mild and optimal intensity of training for rats. Therefore, the training program used in the present study can contribute to improve neurological outcome in MCAO rats.

In summary, the present study demonstrated that treadmill training after focal cerebral ischemia significantly reduces infarct volume and improves neurologic function in MCAO rats. Based on the present findings, one can conclude that treadmill training may be very beneficial for human ischemic brain recovery.

\section{ACKNOWLEDGEMENTS}

This study was supported by NSC 91-2314-B-010-074 from the National Science Council of the Republic of China to Y.R.Y.

\section{REFERENCES}

1. Indredavik B, Slørdahl SA, Bakke F, Rokseth R, Håheim LL. Stroke unit treatment. Long-term effects. Stroke 1997; 28: 1861-1866.

2. Stroke Unit Trialists' Collaboration. Organised inpatient (stroke unit) care after stroke. In: The Cochrane Library, Issue 1, 2000.

3. Ernst E. A review of stroke rehabilitation and physiotherapy. Stroke 1990; 21: 1081-1085.

4. Moseley AM, Stark A, Cameron ID, Pollock A. Treadmill training and body weight support for walking after stroke. In: The Cochrane Library, Issue 4, 2000.

5. Carr JH, Shepherd RB. A Motor Relearning Programme for Stroke. Oxford: Butterworth Heinemann, 1982: 138.

6. Barbeau H, Rossignol S. Recovery of locomotion after chronic spinalization in the adult cat. Brain Res 1987; 412: 84-95.

7. Nudo RJ, Barbay S, Kleim JA. Role of neuroplasticity in functional recovery after stroke. In: Levin HS, Grafman J, (Eds). Cerebral Reorganization of Function after Brain Damage. New York: Oxford University Press, 2000: 168-197.

8. Finch L, Barbeau H, Arsenault B. Influence of body weight support on normal human gait: development of a gait retraining strategy. Phys Ther 1991; 71: 842-856.

9. Smith GV, Silver KH, Goldberg AP, Macko RF. "Task-oriented" exercise improves hamstring strength and spastic reflexes in chronic stroke patients. Stroke 1999; 30: 2112-2118.

10. Silver KH, Macko RF, Forrester LW, Goldberg AP, Smith GV. Effects of aerobic treadmill training on gait velocity, cadence, and gait symmetry in chronic hemiparetic stroke: a preliminary report. Neurorehabil Neural Repair 2000; 14: 65-71.

11. Macko RF, Smith GV, Dobrovolny CL, et al. Treadmill training improves fitness reserve in chronic stroke patients. Arch Phys Med Rehabil 2001; 82: 879-884.

12. Richards CL, Malouin F, Wood-Dauphinee S, et al. Task-specific physical therapy for optimization of gait recovery in acute stroke patients. Arch Phys Med Rehab 1993; 74: 612-620.

13. Hesse S, Bertelt C, Jahnke MT, et al. Treadmill training with partial body weight support compared with physiotherapy in nonambulatory hemiparetic patients. Stroke 1995; 26: 976-981.

14. Robinson RG, Shoemaker WJ, Schlumpf M, Valk T, Bloom FE. Effect of experimental cerebral infarction in rat brain on catecholamines and behaviour. Nature 1975; 255: 332-334.

15. Robinson RG. Differential behavioral and biochemical effects of right and left hemispheric cerebral infarction in the rat. Science 1979; 205: 707-710.

16. Lin TN, He YY, Wu G, Khan M, Hsu CY. Effect of brain edema on infarct volume in a focal cerebral ischemia model in rats. Stroke 1993; 24: 117-121.

17. Wang RY, Yang YR, Yu SM. Protective effects of treadmill training on infarction in rats. Brain Res 2001; 922: 140-143.

18. Siesjo BK. Pathophysiology and treatment of focal cerebral ischemia. Part II: Mechanisms of damage and treatment. J Neurosurg 1992; 77: 337-354.

19. Siesjo BK, Katsura K, Zhao Q, et al. Mechanisms of secondary brain damage in global and focal ischemia: a speculative synthesis. J Neurotrauma 1995; 12: 943-956. 
20. Bederson JB, Pitts LH, Tsuji M, et al. Rat middle cerebral artery occlusion: evaluation of the model and development of a neurologic examination. Stroke 1986; 17: 472-476.

21. Germano IM, Bartkowski HM, Cassel ME, Pitts LH. The therapeutic value of nimodipine in experimental focal cerebral ischemia. Neurological outcome and histopathological findings. J Neurosurg 1987; 67: 81-87.

22. Menzies SA, Hoff JT, Betz AL. Middle cerebral artery occlusion in rat: a neurological and pathological evaluation of a reproducible model. Neurosurgery 1992; 31: 100-107.

23. Swanson RA, Morton MT, Tsao-Wu G, et al. A semiautomated method for measuring brain infarct volume. J Cereb Blood Flow Metab 1990; 10: 290-293.

24. Aspey BS, Cohen S, Patel Y, Terruli M, Harrison MJG. Middle cerebral artery occlusion in the rat: consistent protocol for a model of stroke. Neuropathol Appl Neurobiol 1998; 24: 487-497.

25. Persson L, Hårdemark HG, Bolander HG, Hillered L, Olsson Y. Neurologic and neuropathologic outcome after middle cerebral artery occlusion in rats. Stroke 1989; 20: 641-645.

26. Bederson JB, Pitts LH, Germano SM, et al. Evaluation of 2,3,5triphenyltetrazolium chloride as a stain for detection and quantification of experimental cerebral infarction in rats. Stroke 1986; 17: 1304-1308.

27. Chen ST, Hsu CY, Hogan EL, Maricq H, Balentine JD. A model of focal ischemic stroke in the rat: reproducible extensive cortical infarction. Stroke 1986; 17: 738-743.

28. Liszczak TM, Hedley-Whyte ET, Adams JF, et al. Limitation of tetrazolium salts in delineating infarcted brain. Acta Neuropathol 1984; 65: 150-157.

29. Mackay KB, Bailey SJ, King PD, et al. Neuroprotective effect of recombinant neutrophil inhibitory factor in transient focal cerebral ischemia in the rat. Neurodegeneration 1996; 5: 319323.

30. Witte OW. Lesion-induced plasticity as a potential mechanism for recovery and rehabilitative training. Curr Opin Neurol 1998; 11: 655-662.

31. Witte OW, Stoll G. Delayed and remote effects of focal cortical infarctions: secondary damage and reactive plasticity. Adv Neurol 1997; 73: 207-227.

32. Reinicke S, Lutzenburg M, Hagemann G, Witte OW. Electrophysiological transcortical diaschisis after middle cerebral artery occlusion in rat [abstract]. Eur J Neurosci 1998; 10: 225.

33. Witte OW, Buchkremer-Ratzmann I, Schiene K, et al. Lesioninduced network plasticity in remote brain areas. Trends Neurosci 1997; 20: 348-349.

34. Hagemann G, Redecker C, Neumann-Haefelin T, Freund HJ, Witte OW. Increased long-term potentiation in the surround of experimentally induced focal cortical infarction. Ann Neurol 1998; 44: 255-258.

35. Nudo RJ, Wise BM, SiFuentes F, Milliken GW. Neural substrates for the effects of rehabilitative training on motor recovery after ischemic infarct. Science 1996; 272: 1791-1794.

36. Ostendorf CG, Wolf SL. Effect of forced use of the upper extremity of a hemiplegic patient on changes in function. A single-case design. Phys Ther 1981; 61: 1022-1028.

37. Taub E, Miller NE, Novack TA, et al. Technique to improve chronic motor deficit after stroke. Arch Phys Med Rehab 1993; 74: 347354.

38. Wolf SL, Lecraw DE, Barton LA, Jann BB. Forced use of hemiplegic upper extremities to reverse the effect of learned nonuse among chronic stroke and head-injured patients. Exp Neurol 1989; 104: 125-132.

39. Yu J. Functional recovery with and without training following brain damage in experimental animals: a review. Arch Phys Med Rehabil 1976; 57: 38-41

40. Berne RM, Levy MN, (Eds). Physiology. St. Louis: Mosby-Year Book, 1993: 534-535.

41. Kassell NF, Peerless SJ, Durward QJ, et al. Treatment of ischemic deficits from vasospasm with intravascular volume expansion and induced arterial hypertension. Neurosurgery 1982; 11: 337-343.

42. Auer RN. Non-pharmacologic (physiologic) neuroprotection in the treatment of brain ischemia. Ann NY Acad Sci 2001; 939: 271282.

43. Ide K, Horn A, Secher NH. Cerebral metabolic response to submaximal exercise. J Appl Physiol 1999; 87: 1604-1608.

44. Peerless SJ, Ishikawa R, Hunter IG, Peerless MJ. Protective effect of Fluosol-DA in acute cerebral ischemia. Stroke 1981; 12: 558563.

45. Watson JC, Doppenberg EM, Bullock MR, et al. Effects of the allosteric modification of hemoglobin on brain oxygen and infarct size in a feline model of stroke. Stroke 1997; 28: 16241630.

46. Ginsberg MD, Sternau LL, Globus MY, Dietrich WD, Busto R. Therapeutic modulation of brain temperature: relevance to ischemic brain injury. Cerebrovasc Brain Metab Rev 1992; 4 : 189-225

47. Jones TA, Chu CJ, Grande LA, Gregory AD. Motor skills training enhances lesion-induced structural plasticity in the motor cortex of adult rats. J Neurosci 1999; 19: 10153-10163.

48. Li Y, Jiang N, Powers C, Chopp M. Neuronal damage and plasticity identified by microtubule-associated protein 2 , growth-associated protein 43, and cyclin D1 immunoreactivity after focal cerebral ischemia in rats. Stroke 1998; 29: 1972-1980.

49. Wei J, WeiGang G, Thomas B, Roland R, Per W. Cortical neurogenesis in adult rats after transient middle cerebral artery occlusion. Stroke 2001; 32: 1201-1207.

50. Wei L, Erinjeri JP, Rovainen CM, Woolsey TA. Collateral growth and angiogenesis around cortical stroke. Stroke 2001; 32: 21792184.

51. van Praag H, Kempermann G, Gage FH. Running increases cell proliferation and neurogenesis in the adult mouse dentate gyrus. Nat Neurosci 1999; 2: 266-270.

52. Kleim JA, Cooper NR, VandenBerg PM. Exercise induces angiogenesis but does not alter movement representations within rat motor cortex. Brain Res 2002; 934: 1-6.

53. Ohlsson AL, Johansson BB. The environment influences functional outcome of cerebral infarction in rats. Stroke 1995; 26: 644-649.

54. Johansson BB, Ohlsson AL. Environment, social interaction and physical activity as determinants of functional outcome after cerebral infarction in the rat. Exp Neurol 1996; 139: 322-327.

55. Humm JL, Kozlowski DA, James DC, Gotts JE, Schallert T. Usedependent exacerbation of brain damage occurs during an early postlesion vulnerable period. Brain Res 1998; 783: 286-292.

56. Risedal A, Zeng J, Johansson BB. Early training may exacerbate brain damage after focal brain ischemia in the rat. $\mathrm{J}$ Cereb Blood Flow Metab 1999; 19: 997-1003.

57. Bland ST, Schallert T, Strong R, Aronowski J, Grotta JC. Early exclusive use of the affected forelimb after moderate transient focal ischemia in rats: functional and anatomic outcome. Stroke 2000; 31: 1144-1152. 